Article

\title{
Comparative Study of Essential Oils Extracted from Egyptian Basil Leaves (Ocimum basilicum L.) Using Hydro-Distillation and Solvent-Free Microwave Extraction
}

\author{
Mohammed Chenni ${ }^{1}$, Douniazad El Abed ${ }^{1, *}$, Njara Rakotomanomana ${ }^{2}$, Xavier Fernandez ${ }^{3}$ and \\ Farid Chemat ${ }^{2}$ \\ Received: 17 December 2015 ; Accepted: 15 January 2016 ; Published: 19 January 2016 \\ Academic Editor: Derek J. McPhee \\ 1 Laboratoire de Chimie Fine, Département de Chimie, Faculté des Sciences Exactes et Appliquées, \\ Université d'Oran 1 Ahmed Ben Bella, B.P. 1524, El M'Naouer, Oran 31000, Algeria; \\ chenni.mohamed@hotmail.fr \\ 2 GREEN Extraction Team, INRA, UMR 408, Université d'Avignon et des Pays du Vaucluse, Avignon 84000, \\ France; njara.rakotomanomana@univ-avignon.fr (N.R.); farid.chemat@univ-avignon.fr (F.C.) \\ 3 Institut de Chimie de Nice, UMR 7272, Université de Nice-Sophia Antipolis/CNRS, Parc Valrose, Nice 06108, \\ France; xavier.fernandez@unice.fr \\ * Correspondence: douniazed2000@yahoo.fr; Tel.: +213-664-739-530; Fax: +213-41-519-231
}

\begin{abstract}
Solvent-free microwave extraction (SFME) and conventional hydro-distillation (HD) were used for the extraction of essential oils (EOs) from Egyptian sweet basil (Ocimum basilicum L.) leaves. The two resulting EOs were compared with regards to their chemical composition, antioxidant, and antimicrobial activities. The EO analyzed by GC and GC-MS, presented 65 compounds constituting $99.3 \%$ and $99.0 \%$ of the total oils obtained by SFME and HD, respectively. The main components of both oils were linalool (43.5\% SFME; $48.4 \% \mathrm{HD}$ ), followed by methyl chavicol (13.3\% SFME; $14.3 \% \mathrm{HD}$ ) and 1,8-cineole (6.8\% SFME; 7.3\% HD). Their antioxidant activity were studied with the 2,2-diphenyl-1-picrylhydrazyl $\left(\mathrm{DPPH}^{\bullet}\right.$ ) radical scavenging method. The heating conditions effect was evaluated by the determination of the Total Polar Materials (TPM) content. The antimicrobial activity was investigated against five microorganisms: two Gram-positive bacteria, Staphylococcus aureus and Bacillus subtilis, two Gram-negative bacteria, Escherichia coli and Pseudomonas aeruginosa, and one yeast, Candida albicans. Both EOs showed high antimicrobial, but weak antioxidant, activities. The results indicated that the SFME method may be a better alternative for the extraction of EO from $O$. basilicum since it could be considered as providing a richer source of natural antioxidants, as well as strong antimicrobial agents for food preservation.
\end{abstract}

Keywords: basil (Ocimum basilicum L.); microwave; hydro-distillation; essential oil; chemical composition; GC/MS; antioxidant activity; DDPH assay; antimicrobial activity

\section{Introduction}

Aromatic plants and EOs have been used since ancient times and are still widely used for their biological properties [1,2] and their applications in various industries: food, cosmetics, perfumery, and pharmacy [3]. Nowadays, EOs are attracting substantial interest from scientists because of their use in the treatment of certain infectious diseases for which synthetic antibiotics are becoming less and less active, or for preserving food against oxidation as alternatives to synthetic chemicals.

Ocimum basilicum L., named commonly as sweet basil, is a popular culinary herb belonging to the Lamiaceae family. O. basilicum known as lahbeq in Algeria [4] and called rehan in Arabic [5], is originally 
native to India and other Asian regions. Today, it is cultivated all over the world [6]. Traditionally, the basil leaves are used in folk medicine as a remedy for a large number of diseases, including cancer, convulsion, diarrhea, epilepsy, gout, nausea, sore throat, toothaches, and bronchitis [7-9]. It is also a source of EO containing biologically-active constituents which possess antioxidant and antimicrobial properties [3,5-9]. The chemical composition of basil oil has been the subject of several studies. Basil oils have been classified into four chemotypes according to their chemical composition and geographical source. The European type, cultivated in Europe, USA, and Africa, is characterized by linalool and methyl chavicol as the major oil constituents. The Reunion type, located in the Comoros and Seychelles Islands, Africa, and Reunion Island, is characterized by a high concentration of methyl chavicol. Tropical type originated from India, Pakistan, Guatemala, Haiti, and Africa is rich in methyl cinnamate. Another basil chemotype, with eugenol as the main component, is common in North Africa, Russia, Eastern Europe, and parts of Asia [6,10-12]. In addition to these, other basil oils have also been reported which contained various quantities of linalool, camphor, methyl chavicol, methyl cinnamate, and eugenol [13]. EOs are obtained from plants by various conventional and unconventional processes, such as mechanical pressing, maceration, solvent extraction, supercritical fluid and subcritical water extractions, and HD [14,15]. An original method, the solvent-free microwave extraction (SFME), has been developed and was patented in $2004[16,17]$. SFME is one of the newest techniques for EOs extraction assisted by microwaves, without any solvent or water, at atmospheric pressure. The advantages of using microwave energy are correlated to its effective heating and faster energy transfer and the fact that it is environmentally friendly [18-20]. To the best of our knowledge, there are no previous reports about the comparison of the chemical composition, antioxidant, and antimicrobial activities of the EO of O. basilicum L. leaves isolated by SFME and HD. Therefore, the aim of the present study is to provide data from the comparison between SFME and conventional HD in terms of extraction time, yield, chemical composition, antioxidant, and antimicrobial activities of EO extracted from Egyptian basil leaves.

\section{Results and Discussion}

\subsection{Kinetics of Essential Oils Extracted by SFME and HD}

Figures 1 and 2 represent the kinetics of EO obtained by SFME and HD from dry basil leaves. During the extraction process, the system temperature is equal to the boiling temperature of water at atmospheric pressure $\left(100{ }^{\circ} \mathrm{C}\right)$. To reach this temperature, and thus obtain the distillation of the first EO droplet, it is necessary to heat the sample for only 5 min with SFME against 20 min for HD (Figure 1).

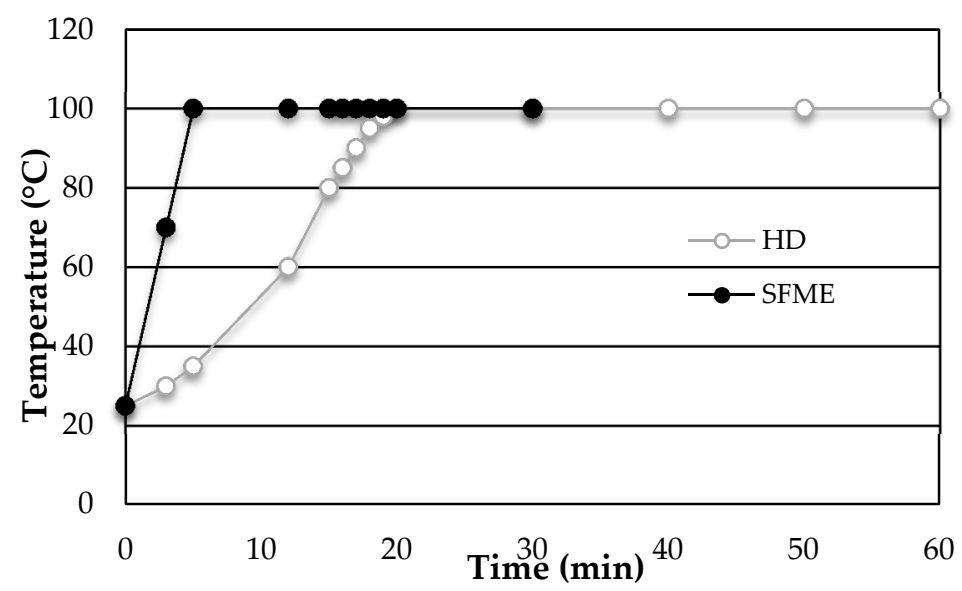

Figure 1. Temperature profiles as a function of time for the SFME $(\bullet)$ and HD $(\bigcirc)$ extraction of EO from sweet basil leaves. 
As shown on Figure 2, an extraction time of $30 \mathrm{~min}$ with SFME provides similar yields $(0.48 \% \pm 0.02 \%)$ to those obtained after $60 \mathrm{~min}$ by HD. The results show that SFME is clearly advantageous with respect to conventional HD in terms of rapidity, efficiency, and substantial energy savings.

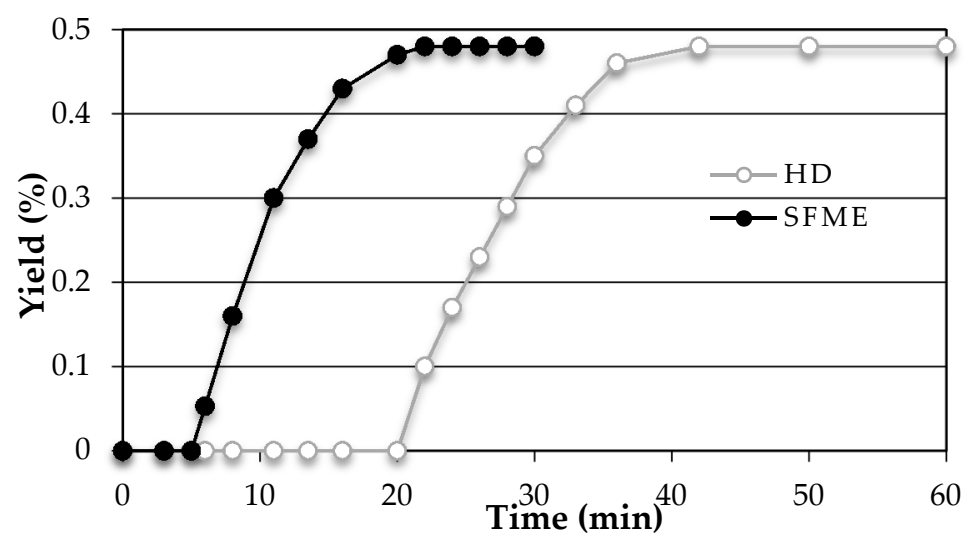

Figure 2. Yield profiles as a function of time for the SFME $(\bullet)$ and HD $(\bigcirc)$ extraction of EO from sweet basil leaves.

\subsection{Evaluation of Physical and Organoleptic Properties}

Physical properties (specific gravity, refractive index, and solubility) and sensory evaluation of EO extracted by SFME and HD from the basil samples are shown in Table 1. There are no significant differences observed between the physical constants of the EO obtained by these two methods. The only difference resides in the color of the EO extracted by SFME which was lighter than that isolated by the classical method. The SFME method offers the possibility for a better reproduction of natural aroma of basil essential oil than the HD method.

Table 1. Physical and organoleptic properties of sweet basil EO obtained by SFME and HD.

\begin{tabular}{ccc}
\hline & \multicolumn{2}{c}{ Extraction Methods } \\
\cline { 2 - 3 } & SFME-EO & HD-EO \\
\hline Physical Properties & 0.926 & 0.917 \\
\hline Specific gravity $\left(20^{\circ} \mathrm{C}\right)$ & 1.486 & 1.480 \\
Refractive index $\left(20^{\circ} \mathrm{C}\right)$ & Water insoluble. Soluble in alcohol and other organic liquids \\
Solubility & & \\
\hline Organoleptic Properties & Pale yellow & Yellow-greenish \\
\hline Color & Sweet minty pleasant odor & Strong and pungent minty odor \\
Odor & Mobile liquid & Mobile liquid \\
Aspect &
\end{tabular}

\subsection{Chemical Composition of the Essential Oils Obtained by SFME and HD}

The components identified by GC and GC-MS in basil (EOs) from both methods are reported in Table 2. The EO of basil leaves isolated either by SFME or HD contains the same dominant components. Among 65 compounds identified in basil EO, representing 99.3 and $99.0 \%$ of the total oils obtained by SFME and HD, respectively, monoterpene, sesquiterpene, and derivatives of phenylpropanoid compounds were identified. Monoterpenes are the main components in the EOs but the relative amounts differ for the two extraction methods. The oxygenated compounds: monoterpene alcohol linalool is the most abundant component in basil EO (43.5\% for SFME and 48.4\% for HD) followed by methyl chavicol (13.3\% for SFME and $14.3 \%$ for HD) and 1,8-cineole (6.8\% for SFME and $7.3 \%$ for 
HD). Slightly lower amounts of oxygenated compounds (89.8\% vs. $89.6 \%$ ) and higher amounts of hydrocarbons (9.7\% vs. 9.2\%) are present in the EO of basil extracted by SFME in comparison with HD. The chemical profile of the basil EO, isolated by SFME and HD in our study, was comparable to that reported by Figueredo et al. [21].

Table 2. Chemical composition of the Egyptian basil essential oils leaves obtained by SFME and HD.

\begin{tabular}{|c|c|c|c|c|c|c|}
\hline No & Compounds $^{1}$ & $\mathrm{LRI}_{\mathrm{HP1}}{ }^{2}$ & LRI INNO $^{2}$ & $\begin{array}{c}\text { HD-EO } \\
(\% \pm \text { SD) }\end{array}$ & $\begin{array}{l}\text { SFME-EO } \\
(\% \pm \text { SD) }\end{array}$ & $\begin{array}{l}\text { Identification } \\
\text { Methods }\end{array}$ \\
\hline \multicolumn{4}{|c|}{ Monoterpenes Hydrocarbons } & 1.9 & 1.3 & \\
\hline 1 & Tricyclene & 915 & 1017 & $\operatorname{tr}$ & $\operatorname{tr}$ & LRI, MS \\
\hline 2 & $\alpha$-Thujene & 919 & 1030 & 0.1 & 0.1 & LRI, MS \\
\hline 3 & $\alpha$-Pinene & 929 & 1070 & 0.2 & 0.1 & LRI, MS, Std \\
\hline 4 & Camphene & 940 & 1072 & 0.1 & 0.1 & LRI, MS, Std \\
\hline 5 & Sabinene & 962 & 1125 & 0.2 & 0.2 & LRI, MS, Std \\
\hline 6 & $\beta$-Pinene & 969 & 1114 & 0.4 & 0.3 & LRI, MS, Std \\
\hline 7 & $\beta$-Phellandrene & 981 & 1167 & 0.3 & 0.2 & LRI, MS, Std \\
\hline 8 & (E)- $\beta$-Ocimene & 1034 & 1249 & 0.2 & 0.1 & LRI, MS, Std \\
\hline 9 & $\gamma$-Terpinene & 1048 & 1245 & $0.4 \pm 0.1$ & 0.2 & LRI, MS, Std \\
\hline 10 & Terpinolene & 1075 & 1285 & $\operatorname{tr}$ & $\operatorname{tr}$ & LRI, MS, Std \\
\hline \multicolumn{4}{|c|}{ Oxygenated Monoterpenes } & 83.2 & 82.9 & \\
\hline 11 & 1,8-cineole & 1026 & 1212 & $7.3 \pm 0.3$ & $6.8 \pm 0.2$ & LRI, MS, Std \\
\hline 12 & Linalool & 1095 & 1552 & $48.4 \pm 0.9$ & $43.5 \pm 0.8$ & LRI, MS, Std \\
\hline 13 & Camphor & 1130 & 1523 & 0.3 & $0.4 \pm 0.1$ & LRI, MS, Std \\
\hline 14 & Menthone & 1145 & 1480 & $0.3 \pm 0.1$ & 0.1 & LRI, MS, Std \\
\hline 15 & Borneol & 1160 & 1700 & $0.8 \pm 0.1$ & $1.0 \pm 0.1$ & LRI, MS, Std \\
\hline 16 & Methyl chavicol & 1181 & 1167 & $14.3 \pm 0.4$ & $13.3 \pm 0.2$ & LRI, MS, Std \\
\hline 17 & Fenchyl acetate & 1198 & 1480 & 0.2 & 0.1 & LRI, MS \\
\hline 18 & Citronellol & 1210 & 1760 & $\operatorname{tr}$ & $\operatorname{tr}$ & LRI, MS, Std \\
\hline 19 & Cuminaldehyde & 1213 & 1780 & $\operatorname{tr}$ & $\operatorname{tr}$ & LRI, MS \\
\hline 20 & Neral & 1215 & 1670 & $\operatorname{tr}$ & $\operatorname{tr}$ & LRI, MS \\
\hline 21 & Carvone & 1217 & 1732 & 0.1 & $\operatorname{tr}$ & LRI, MS, Std \\
\hline 22 & Chavicol & 1231 & 2325 & 0.1 & $\operatorname{tr}$ & LRI, MS \\
\hline 23 & Geraniol & 1235 & 1841 & 0.2 & 0.1 & LRI, MS, Std \\
\hline 24 & Linalyl acetate & 1241 & 1556 & 0.1 & $\operatorname{tr}$ & LRI, MS, Std \\
\hline 25 & Anethol & 1264 & 1825 & 0.7 & 0.6 & LRI, MS, Std \\
\hline 26 & Bornyl acetate & 1271 & 1590 & $1.5 \pm 0.1$ & 1.1 & LRI, MS, Std \\
\hline 27 & (Z)-Methyl cinnamate & 1274 & 1969 & $0.5 \pm 0.1$ & $0.4 \pm 0.1$ & LRI, MS, Std \\
\hline 28 & Myrtenyle acetate & 1299 & 1688 & $\operatorname{tr}$ & $\operatorname{tr}$ & LRI, MS \\
\hline 29 & Eugenol & 1330 & 2155 & $2.4 \pm 0.1$ & $2.9 \pm 0.1$ & LRI, MS \\
\hline 30 & (E)-Methylcinnamate & 1356 & 2091 & $2.3 \pm 0.1$ & $6.5 \pm 0.1$ & LRI, MS, Std \\
\hline 31 & Methyl eugenol & 1371 & 1989 & $3.7 \pm 0.1$ & $6.1 \pm 0.1$ & LRI, MS, Std \\
\hline \multicolumn{4}{|c|}{ Sesquiterpenes Hydrocarbons } & 7.3 & 8.4 & \\
\hline 32 & $\alpha$-Cubebene & 1342 & 1463 & $\operatorname{tr}$ & $\operatorname{tr}$ & LRI, MS \\
\hline 33 & $\beta$-Bourbonene & 1378 & 1542 & 0.2 & $0.2 \pm 0.1$ & LRI, MS \\
\hline 34 & $\beta$-Elemene & 1380 & 1589 & $0.7 \pm 0.1$ & $0.9 \pm 0.1$ & LRI, MS \\
\hline 35 & $\alpha$-Copaene & 1381 & 1490 & 0.1 & 0.2 & LRI, MS, Std \\
\hline 36 & $\beta$-Caryophyllene & 1411 & 1602 & 0.1 & 0.1 & LRI, MS, Std \\
\hline 37 & $\alpha$-Cedrene & 1412 & 1589 & $\operatorname{tr}$ & $\operatorname{tr}$ & LRI, MS \\
\hline 38 & $\beta$-Cubebene & 1413 & 1545 & 0.1 & $\operatorname{tr}$ & LRI, MS \\
\hline 39 & $\alpha$-Bergamotene & 1430 & 1568 & $2.5 \pm 0.1$ & $2.7 \pm 0.2$ & LRI, MS \\
\hline 40 & $\alpha$-Humulene & 1445 & 1667 & $0.2 \pm 0.1$ & $0.3 \pm 0.1$ & LRI, MS, Std \\
\hline 41 & $\alpha$-Guaiene & 1447 & 1597 & $\operatorname{tr}$ & $\operatorname{tr}$ & LRI, MS \\
\hline 42 & $\beta$-Farnesene & 1457 & 1698 & 0.4 & $0.4 \pm 0.1$ & LRI, MS \\
\hline 43 & $\alpha$-Curcumene & 1470 & 1782 & $\operatorname{tr}$ & $\operatorname{tr}$ & LRI, MS \\
\hline 44 & $\gamma$-Muurolene & 1473 & 1669 & 0.1 & 0.2 & LRI, MS \\
\hline 45 & Alloaromadendrene & 1475 & 1637 & 0.3 & $0.4 \pm 0.1$ & LRI, MS \\
\hline 46 & Germacrene D & 1478 & 1705 & 0.8 & $0.9 \pm 0.1$ & LRI, MS \\
\hline 47 & $\delta$-Guaiene & 1492 & 1715 & $0.2 \pm 0.1$ & 0.1 & LRI, MS \\
\hline 48 & $\gamma$-Cadinene & 1505 & 1757 & $1.1 \pm 0.1$ & $1.3 \pm 0.1$ & LRI, MS \\
\hline 49 & Calamenene & 1508 & 1830 & 0.5 & $0.7 \pm 0.1$ & LRI, MS \\
\hline
\end{tabular}


Table 2. Cont.

\begin{tabular}{|c|c|c|c|c|c|c|}
\hline No & Compounds ${ }^{1}$ & $\mathrm{LRI}_{\mathrm{HP1}}{ }^{2}$ & LRI INNO $^{2}$ & $\begin{array}{l}\text { HD-EO } \\
(\% \pm \text { SD) }\end{array}$ & $\begin{array}{l}\text { SFME-EO } \\
(\% \pm \text { SD) }\end{array}$ & $\begin{array}{l}\text { Identification } \\
\text { Methods }\end{array}$ \\
\hline \multicolumn{4}{|c|}{ Oxygenated Sesquiterpenes } & 6.5 & 6.6 & \\
\hline 50 & $\beta$-Ionone & 1455 & 1920 & 0.1 & $\operatorname{tr}$ & LRI, MS, Std \\
\hline 51 & Nerolidol & 1538 & 2009 & $0.3 \pm 0.1$ & $0.4 \pm 0.2$ & LRI, MS, Std \\
\hline 52 & Spathulenol & 1561 & 2131 & $0.4 \pm 0.1$ & $0.6 \pm 0.1$ & LRI, MS \\
\hline 53 & Caryophyllene oxide & 1565 & 1981 & 0.2 & 0.3 & LRI, MS \\
\hline 54 & Carotol & 1592 & 2006 & 0.5 & $0.8 \pm 0.1$ & LRI, MS \\
\hline 55 & Cadinol $^{3}$ & 1615 & 2147 & $0.8 \pm 0.1$ & $0.9 \pm 0.2$ & LRI, MS \\
\hline 56 & $\tau$-Cadinol & 1629 & 2165 & 0.1 & 0.1 & LRI, MS \\
\hline 57 & $\alpha$-Cadinol & 1637 & 2201 & $\operatorname{tr}$ & $\operatorname{tr}$ & LRI, MS \\
\hline 58 & $\alpha$-Bisabolol & 1650 & 2215 & $4.1 \pm 0.1$ & $3.5 \pm 0.1$ & LRI, MS \\
\hline 59 & Phytol & 2080 & - & $\operatorname{tr}$ & $\operatorname{tr}$ & LRI, MS \\
\hline \multicolumn{4}{|c|}{ Other Oxygenated Compounds } & 0.1 & 0.1 & \\
\hline 60 & $\begin{array}{l}\text { Methyl } \\
\text { 2-methylbutyrate }\end{array}$ & 758 & 1008 & $\operatorname{tr}$ & - & LRI, MS \\
\hline 61 & Hexanal & 773 & 1090 & $\operatorname{tr}$ & $\operatorname{tr}$ & LRI, MS, Std \\
\hline 62 & (Z)-2-Hexenal & 823 & 1120 & $\operatorname{tr}$ & $\operatorname{tr}$ & LRI, MS, Std \\
\hline 63 & Benzyl benzoate & 1710 & 2571 & $\operatorname{tr}$ & $\operatorname{tr}$ & LRI, MS, Std \\
\hline 64 & $\begin{array}{l}\text { 6,10,14-Trimethyl } \\
\text { pentadecan-2-one }\end{array}$ & 1816 & - & 0.1 & 0.1 & LRI, MS \\
\hline 65 & Farnesyl acetone & 1867 & 2382 & $\operatorname{tr}$ & $\operatorname{tr}$ & LRI, MS \\
\hline & Extraction time & & & $60 \mathrm{~min}$ & $30 \mathrm{~min}$ & \\
\hline & Yields \% & & & $0.48 \% \pm 0.02 \%$ & $0.48 \% \pm 0.02 \%$ & \\
\hline & Total oxygenated com & and & & 89.8 & 89.6 & \\
\hline & Total non-oxyge & ed compor & & 9.2 & 9.7 & \\
\hline & Total identifi & compound & & 99.0 & 99.3 & \\
\hline
\end{tabular}

\footnotetext{
${ }^{1}$ Compounds are listed in order of their classes. Compositional values less than $0.1 \%$ are denoted as traces (tr). Presence of a compound is indicated by its GC-FID percentage with S.D. = standard deviation, absence is indicated by " $-{ }^{\prime} ;{ }^{2} \mathrm{RI}=$ retention indices are determined on HP-1 and INNOWAX column using the homologous series of n-alkanes (C8-C24); ${ }^{3}$ Correct isomer not identified.
}

A substantial number of studies conducted on the composition of the EO of basil revealed a huge diversity in the constituents of its oil with different chemotypes from many regions of the world. It can be described from Table 3 that the major constituents which have been isolated from different O. basilicum oils include linalool, methyl chavicol, eugenol, methyl cinnamate, 1,8-cineole, bergamotene, limonene, camphor, $\alpha$-cardinol, geraniol, etc. [22]. In the Brazilian basil leaf EOs [23], linalool, geraniol, and 1,8-cineole are the major compounds corroborating with Oman basil [5], as well as Poland [24] basil. For Czech Republic [25], Guinea [26], and Reunion [18], the major compounds of basil EO are linalool and eugenol. Marotti et al. [10] reported the presence of linalool, methyl chavicol, and eugenol as main components of Italian basil EO. It was also reported that four major compounds characterize the basil EO of Austria: linalool, methyl chavicol, methyl cinnamate, and $\alpha$-cadinol [27]. These results are consistent with those obtained in previous works in Bulgaria [28] and USA [29]. In O. basilicum EO from Romania [30], linalool was reported as the main component. The major compounds of EO extracted from Algeria [31] leaves of basil, were linalool, linalyl acetate, elemol, and geranyl acetate. However, the first major compound from French Polynesia basil leaf EOs [32] is methyl cinnamate. Regarding Pakistan basil [33], four major compounds were found: linalool, epi- $\alpha$-cardinol, $\alpha$-bergamotene, and $\gamma$-cadinene. In the case of Egypt basil oils, Ismail [34] has reported linalool, 1,8-cineole, eugenol, and methyl cinnamate as dominant components. Concerning basil from Turkey, Chalchat et al. [35] cited three major compounds: methyl chavicol, limonene, and $p$-cymene. Additionally, the EO from Madagascar [36], Iran [37], and Thailand [38] is rich in methyl chavicol. On the other hand, Purkayastha [39] reported that camphor, followed by limonene and $\beta$-selinene were the major compounds in O. basilicum EO from Northeast India. According to Simon et al. [6], the Egyptian basil is very similar to the European, characterized by linalool and methyl chavicol as the major oil constituents that were in agreement to our results that the essential oil of basil belonged 
to the linalool-rich type. The observed difference in the constituents of basil EOs between countries may be probably due to environmental conditions and genetic factors, different chemotypes, and the nutritional elements of the plants, as well as other factors that can influence the oil composition.

Table 3. Composition of the main compounds of O. basilicum L. essential oil from different countries.

\begin{tabular}{|c|c|c|c|}
\hline Country & Part Used & Major Constituents (\%) & Reference \\
\hline Oman & Plants & $\begin{array}{l}\text { Linalool (69.9), geraniol (10.9), 1,8-cineole (6.4), } \alpha \text {-bergamotene (1.6), } \\
\text { geranyl acetate (1.4) }\end{array}$ & [5] \\
\hline Italy & Fresh aerial parts & $\begin{array}{l}\text { Linalool (41.17-76.20), methyl chavicol (18.01-41.40), } \\
\text { eugenol (1.16-3.89), 1,8-cineole (0.94-12.91) }\end{array}$ & [10] \\
\hline Reunion & Fresh plants & $\begin{array}{l}\text { Linalool (25.3-39.1), eugenol (11.0-43.2), } \\
\text { trans- } \alpha \text {-bergamotene }(6.0-7.6)\end{array}$ & [18] \\
\hline Brazil & Dried leaves & Linalool (72.14), geraniol (12,95), 1,8-cineole (7.90) & [23] \\
\hline Poland & Dried plants & Linalool (64.7), geraniol (12.6), 1,8-cineole (4.1), epi- $\alpha$-cadinol (3.8) & [24] \\
\hline $\begin{array}{l}\text { Czech } \\
\text { Republic }\end{array}$ & Fresh leaves & $\begin{array}{l}\text { Linalool (15.6-32.2), eugenol (9.1-22.2), 1,8-cineole (3.1-20.2), } \\
\text { bergamotene (1-20.2) }\end{array}$ & [25] \\
\hline Guinea & Plants & Linalool (69.0), eugenol (10.0), (E)- $\alpha$-bergamotene (3.0), thymol (2.0) & [26] \\
\hline Austria & Dried leaves & $\begin{array}{l}\text { Linalool (28.6), methyl chavicol (21.7), (E)-methyl cinnamate (14.3), } \\
\alpha \text {-cadinol (7.1), eugenol (5.9), 1,8-cineole (4.0) }\end{array}$ & [27] \\
\hline Bulgaria & Dried leaves & Linalool (54.95), methyl chavicol (11.98), methyl cinnamate (7.24) & [28] \\
\hline USA & Dried leaves & Linalool (3.94), methyl chavicol (2.03), methyl cinnamate (1.28) & [29] \\
\hline Romania & Dried plants & $\begin{array}{l}\text { Linalool (46.95), } \beta \text {-elemene (7.84), farnesene (6.86), } \\
\text { epi-bicyclosesquiphellandrene (5.92), } \alpha \text {-guaiene (5.26) }\end{array}$ & [30] \\
\hline Algeria & Dried leaves & $\begin{array}{l}\text { Linalool (32.83), linalyl acetate (16), elemol (7.44), } \\
\text { geranyl acetate (6.18), myrcene (6.12), allo-ocimene (5.02), } \\
\alpha \text {-terpineol (4.9), (E)- } \beta \text {-ocimene (3.68), neryl acetate (3.45) }\end{array}$ & [31] \\
\hline $\begin{array}{l}\text { French } \\
\text { Polynesia }\end{array}$ & Fresh leaves & $\begin{array}{l}\text { (E)-methyl cinnamate (43.4-62.3), (Z)-methyl cinnamate (8.1-8.6), } \\
\text { linalool (4.6-21.9) }\end{array}$ & [32] \\
\hline Pakistan & Dried aerial parts & $\begin{array}{l}\text { Linalool (56.7-60.6), epi- } \alpha \text {-cadinol (8.6-11.4), } \alpha \text {-bergamotene } \\
(7.4-9.2), \gamma \text {-cadinene }(3.2-5.4)\end{array}$ & [33] \\
\hline Egypt & Aerial parts & $\begin{array}{l}\text { Linalool (44.18), 1,8-cineole (13.65), eugenol ( } 8.59) \text {, } \\
\text { methyl cinnamate (4.26), iso-caryophyllene (3.10), } \alpha \text {-cubebene (4.97) }\end{array}$ & [34] \\
\hline Turkey & Flower, leaves, stem & $\begin{array}{l}\text { Methyl chavicol }(58.26,52.60,15.91), \text { limonene }(19.41,13.64,2.40) \text {, } \\
\text {-cymene }(0.38,2.32,2.40)\end{array}$ & [35] \\
\hline Madagascar & Plants & $\begin{array}{l}\text { Methyl chavicol (74-87), 1,8-cineole (2.55-4.43), linalool (0.97-2.72), } \\
\text { methyl eugenol (0.87-4.16) }\end{array}$ & [36] \\
\hline Iran & Dried leaves & $\begin{array}{l}\text { Methyl chavicol (46.9), geranial (19.1), neral (15.15), geraniol (3.0), } \\
\text { nerol (3.0), caryophyllene (2.4) }\end{array}$ & [37] \\
\hline Thailand & Aerial parts & Methyl chavicol (92.48), $\beta$-ocimene (2.27), trans- $\alpha$-bergamotene (2.14) & [38] \\
\hline India & Aerial parts & Camphor (42.1), limonene (7.6), $\beta$-selinene (5.6) & [39] \\
\hline
\end{tabular}

\subsection{Antioxidant Activity}

The free radical scavenging activity of basil EOs was measured by the DPPH assay. The DPPH* radical is one of the most commonly used substrates for the fast evaluation of antioxidant activity because of its stability in radical form and the simplicity of the assay. O. basilicum EOs were able to reduce the stable, purple-colored radical DPPH-into yellow-colored DPPH-H [40]. The results of antioxidant activity of $O$. basilicum $\mathrm{EO}$ are reported in Figure 3 (the experiments were done in triplicate). It can be seen that $O$. basilicum EO extracted by SFME exhibited a dose dependent increase with a radical scavenging effect of $86.13 \% \pm 2.8 \%$ at $20 \mathrm{mg} / \mathrm{mL}$, which is higher than the DPPH $\%$ inhibition of the O. basilicum EO extracted by HD (76.13\% $\pm 2.6 \%)$ at the same concentration. The DPPH $\%$ inhibition of the $\alpha$-tocopherol $(90.74 \% \pm 0.2 \%)$ at $5 \mathrm{mg} / \mathrm{mL}$ is higher than the DPPH\% inhibition of the $O$. basilicum. DPPH scavenging activity is usually presented by the value of $\mathrm{IC}_{50}$ (concentration that inhibits $50 \%$ of the DPPH radical). A comparison between the DPPH scavenging activity of O. basilicum EOs (SFME-EO IC $\mathrm{I}_{50}=3.6 \mathrm{mg} / \mathrm{mL}, \mathrm{HD}-\mathrm{EO} \mathrm{IC}_{50}=8.1 \mathrm{mg} / \mathrm{mL}$ ) and those expressed by $\alpha$-tocopherol $\left(\mathrm{IC}_{50}=0.8 \mathrm{mg} / \mathrm{mL}\right)$ showed that the $\mathrm{EO}$ exhibited weakest antioxidant effects than 
$\alpha$-tocopherol (vitamin E). Therefore, the antioxidant effect of the oil was about four times lower for SFME-EO and 10 times lower for HD-EO than that of the standard antioxidant. Previous studies have shown that $O$. basilicum has potent antioxidant properties [5,41-45]. Our findings are in agreement with Hadj-Khelifa et al. [31] who reported that O. basilicum EO containing linalool as a major compound exhibited lower antioxidant effects $\left(\mathrm{IC}_{50}=83.4 \mathrm{mg} / \mathrm{mL}\right)$ than the vitamin $\mathrm{E}\left(\mathrm{IC}_{50}=22.0 \mathrm{mg} / \mathrm{mL}\right)$. Hussain et al. [33] showed that sweet basil EO which is rich in linalool offered antioxidant activity comparable to synthetic antioxidant BHT. However, Bozin et al. [46] found that basil oil containing methyl chavicol (45.8\%) and linalool (24.2\%) as major components exhibited very strong RSA, reducing the $\mathrm{DPPH}$ radical formation $\left(\mathrm{IC}_{50}\right)$ in the range of $0.4 \mu \mathrm{g} / \mathrm{mL}$, and indicated that the most responsible compounds were the oxygenated phenolic monoterpene methyl chavicol and the mixture of mono and sesquiterpene hydrocarbons. Quite a different situation was observed by Mahmoud et al. [47], which found that the main component methyl chavicol exhibit a moderate antioxidant activity (DPPH assay). Also, Dawidowicz et al. [48] which showed that the main component methyl chavicol, do not exhibit antioxidant properties. The antioxidant properties of basil EOs ( $\mathrm{I} \%$ about $46.1 \% \pm 1.3 \%$ ) result from the properties of other components, especially methyl eugenol that was considered as the main contributors of the antioxidant activity in the EO of Myrtus communis L. [49]. Politeo et al. [27] clearly suggests that the antioxidant capacity $\left(\mathrm{IC}_{50}\right.$ values of $\left.1.4 \mathrm{~g} / \mathrm{L}\right)$ of total $\mathrm{EO}$ is due only or mainly to the presence of eugenol $(5.9 \%)$ in its chemical composition and that other constituents do not have significant effect on eugenol capacity. The antioxidant activity of eugenol has been reported several times, tested on various systems [50-52]. In accordance, Pripdeevech et al. [53] reported that the EO of O. basilicum from Thailand (linalool/eugenol chemotype) exhibited high scavenging ability of DPPH radicals $\left(\mathrm{IC}_{50}=26.53 \pm 0.94 \mu \mathrm{g} / \mathrm{mL}\right)$. The same finding was reported by Dabire et al. [54] who showed that the decrease in the rate of eugenol in $\mathrm{EO}$ of $\mathrm{O}$. basilicum causes a decrease of its antioxidant power. Lee et al. [29] also found that eugenol $(0.896 \mathrm{mg} / \mathrm{g})$ was the main contributor of the antioxidant activity of volatile extract of basil than major components. Hence, the main component does not always determine the antioxidant activity of the examined EOs. It is possible that components present at lower concentrations might be involved in some type of synergy with other active compounds. Our study indicated than the antioxidant activity of SFME-EO was relatively more active than HD-EO. As a result, the antioxidant activity of O. basilicum EO may be attributed to the higher content of linalool, methyleugenol, eugenol, and other minor components.

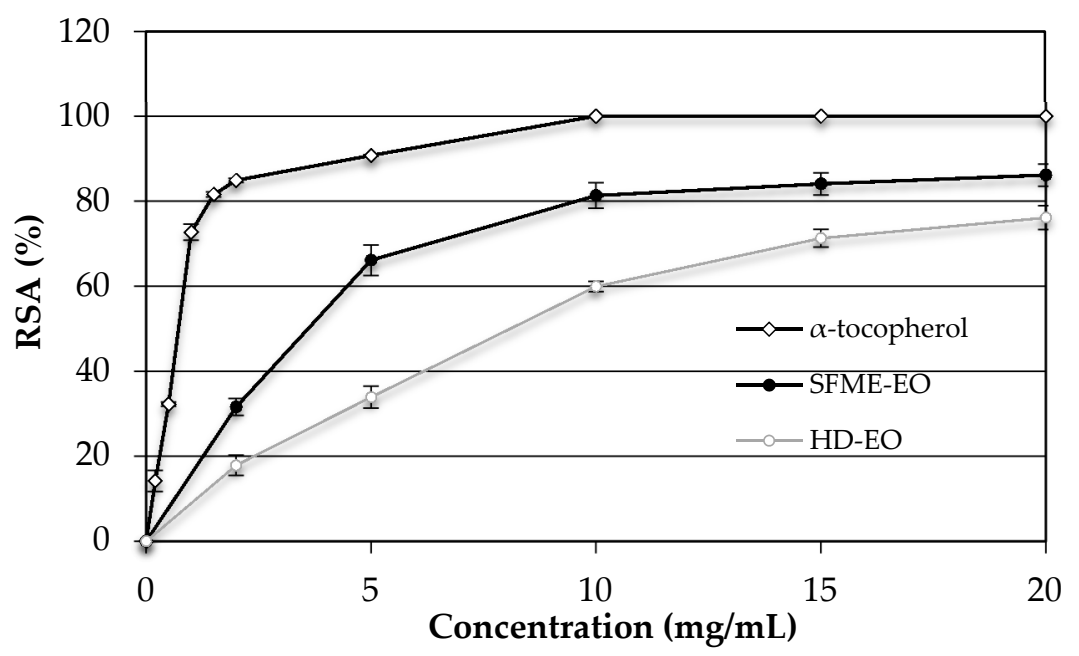

Figure 3. Evaluation of antioxidant activity of basil essential oils ( $\bullet$ SFME-EO $\bigcirc \mathrm{HD}-\mathrm{EO} \diamond \boldsymbol{\alpha}$-tocopherol).

\subsection{Oil Enrichment and Heating Test}

All the samples containing OO displayed close TPM values before heating but the total heating times required to reach the maximal TPM value of $25 \%$ were quite different: $4.7 \pm 0.1 \mathrm{~h}$ for $\mathrm{OO}$, 
$6.6 \pm 0.1 \mathrm{~h}$ for OO-HD-EO and $7.8 \pm 0.1 \mathrm{~h}$ for OO-SFME-EO (Figure 4 ). Hence, the efficient EO supplementation of $\mathrm{OO}$ would significantly prolong the $\mathrm{OO}$ shelf life. The results show a high level of stability of virgin $\mathrm{OO}$ enriched with basil EO, especially those isolated by SFME. These results are in good agreement with other findings in the literature [55-57], which TPM effect might be attributed to the phenolic compounds present in the EO, although there is no specific report carried out about basil oils on fried $\mathrm{OO}$.

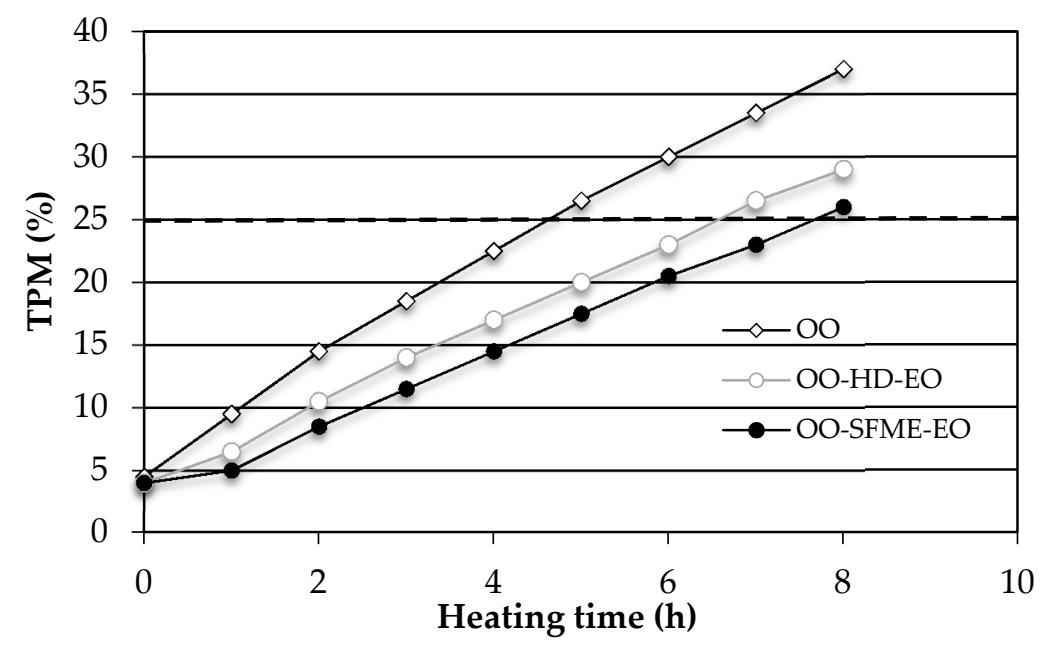

Figure 4. Comparison of TPM during the frying process (at $180^{\circ} \mathrm{C}$ ) of olive oil containing basil essential oils $(\bullet$ OO-SFME-EO; $\bigcirc$ OO-HD-EO) and virgin olive oil $(\diamond \mathrm{OO})$.

\subsection{Antimicrobial Activity}

The antimicrobial activity of sweet basil oil was tested against five pathogenic microorganisms. The results obtained from disc diffusion method (Figure 5), followed by measurement of minimum inhibitory concentration (MIC) represented in Table 4, indicated that $S$. aureus was the most sensitive microorganisms showing largest inhibition zones $(38-33 \mathrm{~mm})$ and lowest MIC values $(18-25 \mu \mathrm{L} / \mathrm{mL})$. The lowest activity was observed against $E$. coli with the smallest inhibition zones (26-22 $\mathrm{mm})$ and highest MIC value (25-30 $\mathrm{L} / \mathrm{mL})$. Furthermore, growth inhibition was also prone to fungi C. albicans with inhibition zones (34-31 mm) and MIC value (30-40 $\mu \mathrm{L} / \mathrm{mL})$. Overall, the EOs of basil displayed a broad antimicrobial spectrum and exerted a much stronger antimicrobial effect against Gram-positive than against Gram-negative bacteria. These results are in accordance with the literature data $[41,46]$. The antimicrobial activity of the basil EO obtained by SFME is relatively higher than that obtained with HD. The EO of $O$. basilicum has been reported previously to have a good antimicrobial activity against a wide range of microorganisms [28,37,46,58,59]. Many authors have linked basil antimicrobial effects to the presence of high content of linalool. Thereby, Hussain et al. [33] reported that O. basilicum EO and linalool showed greater activity against bacterial strains than antifungal strains. Additionally, Hanif et al. [5] showed that Omani basil EO founded with higher linalool exhibited strong antibacterial activity against all the bacteria tested except $P$. putida and $P$. aeruginosa. Ouibrahim et al. [60] studied the antibacterial activity of Algerian basil EO, which is rich in linalool, against a wide range of Gram-negative and Gram-positive bacteria. They found that this oil is efficient in all tested bacterial strains except $P$. aeruginosa. Sienkiewicz et al. [61] demonstrated that basil oils containing mainly methyl chavicol $(86.4 \%)$ can be widely used to eliminate clinical strains of E. coli found in different clinical conditions. Moghaddam et al. [62] revealed that the EO predominantly contains methyl chavicol $(87.6 \%)$, which has antibacterial activity against all of the tested bacteria. These findings contradict those obtained by Lopez et al. [63] who reported that methyl chavicol has no relevance in the antimicrobial effects of the tested basil EOs in the vapor phase. By comparing the results of other researchers, it is possible to notice that for EOs tested, no significant correlation between the antibacterial activity and the percentage of the major components has been found. The different 
antibacterial activity exhibited by the oils, can be explained by either the synergistic effect of the different components in the oil and/or by the presence of other components that may be active even in small concentrations $[43,64,65]$. The antibacterial activity of EO from $O$. basilicum may be due in part to the presence of high content of linalool and methyl chavicol as the main components. However, between the two extracts of sweet basil, SFME-EO was relatively more active than HD-EO, which might be attributed to the high contents of (E)-methyl cinnamate, methyl eugenol, eugenol, and other oxygenated compounds in SFME-EO.

Table 4. Result of antimicrobial activity of sweet basil EO obtained by SFME and HD.

\begin{tabular}{lcccc}
\hline \multirow{2}{*}{ Tested Microorganisms } & \multicolumn{2}{c}{$\begin{array}{c}\text { Inhibition Diameter }{ }^{1} \\
\left(\mathbf{m m} \pm \text { Standard Deviation }{ }^{2}\right)\end{array}$} & \multicolumn{2}{c}{$\begin{array}{c}\text { Minimum Inhibitory } \\
\text { Concentration }(\mu \mathrm{L} / \mathbf{m L})\end{array}$} \\
\cline { 2 - 5 } & SFME-EO & HD-EO & SFME-EO & HD-EO \\
\hline Gram-Positive Bacteria & & & & \\
\hline Staphylococcus aureus (ATCC 6538) & $38 \pm 1.5$ & $33 \pm 2.5$ & 18 & 25 \\
Bacillus subtilis (ATCC 6633) & $37 \pm 2.9$ & $34 \pm 1.2$ & 18 & 30 \\
\hline Gram-Negative Bacteria & & & & 30 \\
\hline Escherichia coli (ATCC 25922) & $26 \pm 2.1$ & $22 \pm 2.0$ & 25 & 40 \\
Pseudomonas aeruginosa (ATCC 14028) & $29 \pm 2.3$ & $20 \pm 3.2$ & 20 & \\
\hline Yeast & & & & 30 \\
\hline Candida albicans (ATCC 10231) & $34 \pm 2.3$ & $31 \pm 2.3$ & & \\
\hline
\end{tabular}

${ }^{1}$ Diameter of inhibition zone $(\mathrm{mm})$ including disc diameter of $6 \mathrm{~mm} ;{ }^{2}$ Each value is the mean $\pm \mathrm{SD}$ of three replications.
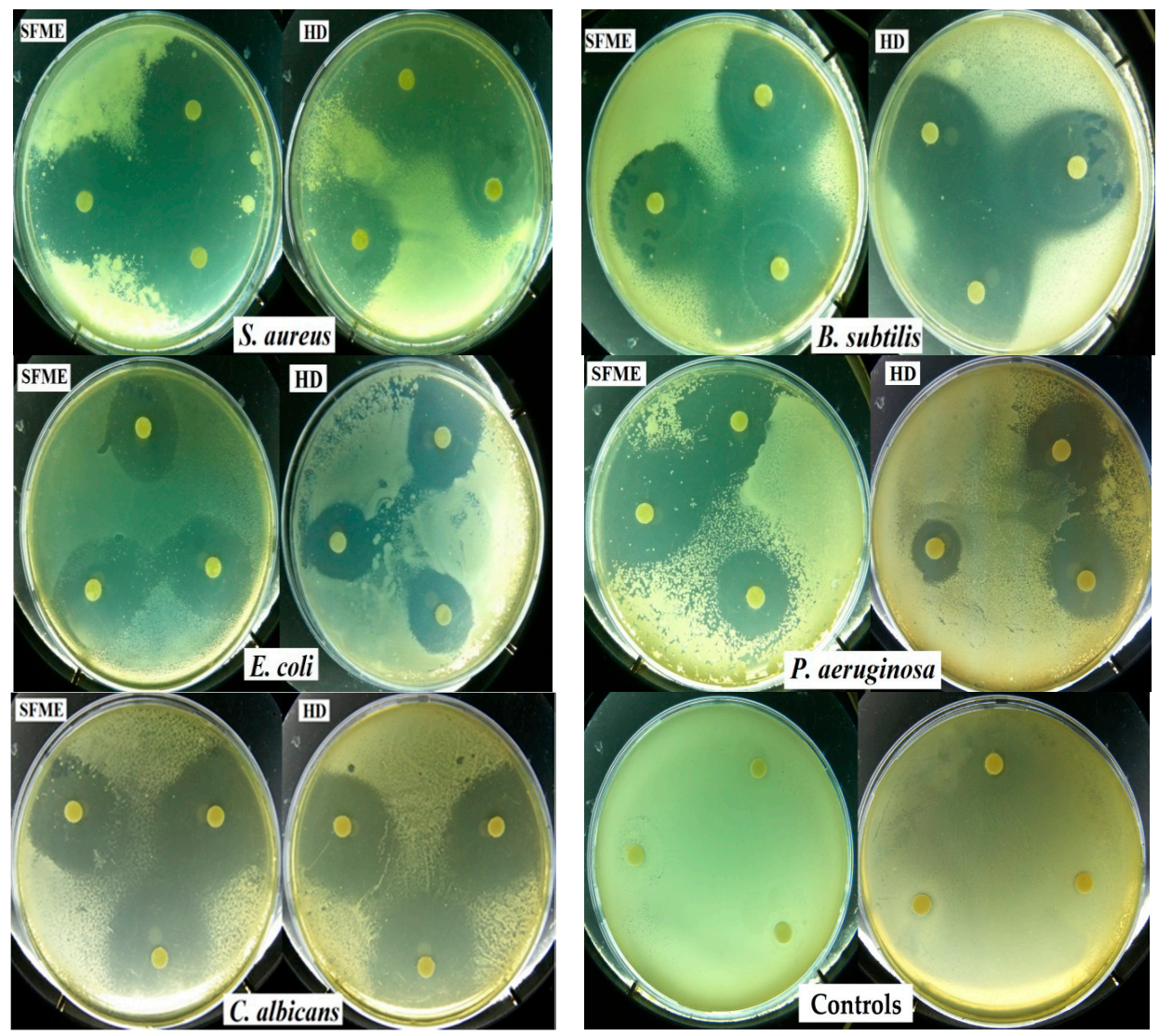

Figure 5. Photograph showing inhibition zones of the microbial growth of all tested microorganisms and control. 


\section{Materials and Methods}

\subsection{Plant Materials}

Sweet basil broken leaves $(9.4 \% \pm 0.4 \%$ of humidity) were purchased from Dios herbarium of organic agriculture product, F26410-Chatillon in Dios-France. Ocimum basilicum L. were collected from Egypt in 2011 and $n^{\circ} 28587$.

\subsection{Extraction Methods}

\subsubsection{Solvent-Free Microwave Apparatus and Procedure}

SFME was performed in a Milestone "DryDist" microwave laboratory (Milestone, Bergamo, Italy). This is a multimode $2.45 \mathrm{MHz}$ microwave reactor with a maximum delivered power of $1000 \mathrm{~W}$. Temperature was monitored by use of an external infrared (IR) sensor. During experiments, time, temperature, pressure, and power can be controlled. The experiment was conducted at atmospheric pressure with $150 \mathrm{~g}$ of $O$. basilicum immersed in water $(600 \mathrm{~g})$ during $30 \mathrm{~min}$ at $600 \mathrm{~W}$. The plant material was heated by using a fixed power density of $1.0 \mathrm{~W} \cdot \mathrm{g}^{-1}$ for $30 \mathrm{~min}$. A cooling system outside the microwave cavity condensed the distillate continuously with a Clevenger-type apparatus. Condensed water was returned to the flask and heating was continued at $100{ }^{\circ} \mathrm{C}$ until no more essential oil was obtained. The essential oil was collected, dried over anhydrous sodium sulfate, and stored at $4{ }^{\circ} \mathrm{C}$ until used.

\subsubsection{Hydro-Distillation Apparatus and Procedure}

In this method, $150 \mathrm{~g}$ of $O$. basilicum immersed in $6 \mathrm{~L}$ water were submitted to hydro-distillation with a Clevenger-type apparatus for $1 \mathrm{~h}$ (until no more essential oil was obtained). The essential oil was collected, dried with anhydrous sodium sulfate, and stored at $4{ }^{\circ} \mathrm{C}$ until used.

\subsection{GC and GC-MS Identification}

\subsubsection{Gas Chromatography by Flame Ionic Detector (FID)}

GC analysis was carried out using an Agilent 6890N gas chromatograph, under the following operation conditions: vector gas, Helium; injector and detector temperatures, $250{ }^{\circ} \mathrm{C}$; injected volume, $1.0 \mu \mathrm{L}$; split ratio 1/100; HP1 column (J and W Scientific, Folsom, CA, USA), polydimethylsiloxane (50 m $\times 0.20 \mathrm{~mm}$ i.d., film thickness $0.33 \mu \mathrm{m}$; constant flow $1 \mathrm{~mL} / \mathrm{min}$ ) and INNOWAX (polyethyleneglycol, $50 \mathrm{~m} \times 0.20 \mathrm{~mm}$ i.d. $\times$ film thickness $0.4 \mu \mathrm{m}$; Interchim, Montluçon, France). Temperature program $45-250^{\circ} \mathrm{C}$ at $2{ }^{\circ} \mathrm{C} / \mathrm{min}$ and $250^{\circ} \mathrm{C}$ for $60 \mathrm{~min}$. Retention indices were determined with C5 to C24 alkane standards as reference. Relative amounts of individual components are based on peak areas obtained without FID response factor correction. Three replicates were performed for each sample. The average of these three values and the standard deviation were determined for each component identified.

\subsubsection{Gas Chromatography-Mass Spectrometry Analysis}

GC-MS analysis was carried out using an Agilent 6890N coupled to an Agilent 5973 MS (Agilent, Massy, France). Samples were analyzed on a fused-silica capillary column HP-1 (polydimethylsiloxane, $50 \mathrm{~m} \times 0.20 \mathrm{~mm}$ i.d. $\times$ film thickness $0.33 \mu \mathrm{m}$; Interchim) and INNOWAX (polyethyleneglycol, $50 \mathrm{~m} \times 0.20 \mathrm{~mm}$ i.d. $\times$ film thickness $0.4 \mu \mathrm{m}$; Interchim). Operation conditions: carrier gas, helium constant flow $1 \mathrm{~mL} / \mathrm{min}$, injector temperature, $250^{\circ} \mathrm{C}$, split ratio, $1: 100$, temperature program, $45^{\circ} \mathrm{C}$ to $250{ }^{\circ} \mathrm{C}$ or $230{ }^{\circ} \mathrm{C}$, at $2{ }^{\circ} \mathrm{C} / \mathrm{min}$ then held isothermal $\left(20 \mathrm{~min}\right.$ ) at $250{ }^{\circ} \mathrm{C}$ (apolar column) or $230{ }^{\circ} \mathrm{C}$ (polar column), ion source temperature, $230{ }^{\circ} \mathrm{C}$; transfer line temperature, $250{ }^{\circ} \mathrm{C}$ (apolar column) or $230^{\circ} \mathrm{C}$ (polar column); ionization energy, $70 \mathrm{eV}$; electron ionization mass spectra were acquired over the mass range 35-400 amu. 


\subsubsection{Identification of the Components}

Identification of the components was based on computer matching against commercial libraries (Wiley, MassFinder 2.1 Library, and NIST98), laboratory mass spectra libraries built up from pure substances, and MS literature data [66-69] combined with comparison of GC retention indices (RI) on apolar and polar column. RIs were calculated with the help of a series of linear alkanes C8-C24 on apolar and polar column (HP-1 and HP-INNOWAX). Compounds available in the laboratory were confirmed by external standard compound co-injection.

\subsection{Physical Constants and Organoleptic Properties}

Basil essential oils have been analyzed according to the standard method AFNOR [70]. The usual physical constants (specific gravity and refractive index) defining the $\mathrm{EO}$ have been determined at $20{ }^{\circ} \mathrm{C}$. The organoleptic properties of the two basil EOs (SFME-EO and HD-EO) were analyzed by sensory evaluation. These tests were conducted by a panel comprising 10 graduate students from the University of Oran 1 Ahmed Benbella, Algeria. The samples presented to each panelist were evaluated as seen on Table 1 according to the following attributes: color, odor, and aspect.

\subsection{Antioxidant Activity}

The antioxidant activity of the O. basilicum EO was evaluated by the DPPH assay. DPPH (2,2-diphenyl-1-picrylhydrazyl) is a stable, highly-colored free radical that can abstract labile hydrogen atoms from phenolic antioxidants with concomitant formation of a yellow hydrazine (DPPH-H) [40]. The free radical-scavenging activity (RSA) of an extract can be expressed as the percentage of DPPH reduced by a given amount of extract. RSA was measured, following the modified method of Achat et al. [55]. Briefly, O. basilicum oil was subjected to serial dilutions in methanol to obtain different concentrations $(2-20 \mathrm{mg} / \mathrm{mL}) .50 \mu \mathrm{L}$ of each solution were added to $2 \mathrm{~mL}$ of a DPPH solution $\left(2 \times 10^{-4} \mathrm{~mol} / \mathrm{L}\right.$ in methanol) and the mixture was left in the dark at room temperature for $30 \mathrm{~min}$. The absorbance was then measured at $517 \mathrm{~nm}$ using a spectrophotometer. Free radical inhibition by DPPH was calculated in percent (\%) according to the following equation:

$$
\% \operatorname{RSA}=\left(\frac{\mathrm{A}_{0}-\mathrm{A}_{\mathrm{i}}}{\mathrm{A}_{0}}\right) \times \mathbf{1 0 0}
$$

$\mathrm{A}_{0}$ : absorbance of DPPH solution without any antioxidant. $\mathrm{A}_{\mathrm{i}}$ : absorbance of DPPH solution after reaction with EO.

All experiments were performed in triplicate.

The $\mathrm{IC}_{50}$ value, which represents the EO concentration that caused neutralization of $50 \% \mathrm{DPPH}$ radicals, was determined from the plot of the inhibition percentage against concentration. The capacity of each antioxidant was compared with the $\alpha$-tocopherol (vitamin E) standard using the same methodology for various concentrations $(0.2-5 \mathrm{mg} / \mathrm{mL})$.

\subsection{Heating Conditions}

The effect of heating conditions was studied through the determination of the amount of total polar materials (TPMs) which assemble the different groups of altered compounds (free fatty acids, mono and diglycerides) and the oxidation and polymeric derivatives, all formed at temperatures below $180{ }^{\circ} \mathrm{C}$ (French law No. 86-857) [71]. $200 \mu \mathrm{g}$ of either SFME-EO or HD-EO were added to $200 \mathrm{~g}$ of virgin olive oil (OO). The samples were then heated under domestic frying conditions, i.e., at $(180 \pm 5){ }^{\circ} \mathrm{C}$ during several hours [56]. The temperature was monitored by a thermocouple (ATC-300) inserted directly into the domestic deep-fat electric fryers. All samples were analyzed before the first heating session and then every hour until degradation of the oil. The end of the heating assay was reached according to the maximum TPM value of $25 \%$ as tolerated by the French law (Article 3-3 of decree No. 86-857 of 18/07/86) and as mandatory in several countries [71]. The TPM percentage 
is determined using a Testo probe which tests quickly the quality of oil via the measurement of the dielectric constant. All the measurements were performed in duplicate.

\subsection{Antimicrobial Activity}

\subsubsection{Disc Diffusion Method}

Antimicrobial activities of the essential oils were determined by the paper disc diffusion method [72,73]. For these assays, cultures of the following microorganisms were used: two Gram-positive (Staphylococcus aureus ATCC 6538 and Bacillus subtilis ATCC 6633), two Gram-negative (Escherichia coli ATCC 25922 and Pseudomonas aeruginosa ATCC 14028) bacteria, and one yeast (Candida albicans ATCC 10231). All microorganisms were supplied by the Algerian Pasteur Institute. The cultures of microorganisms were maintained on nutrient agar (NA) medium. Briefly, suspensions of the tested microorganisms $\left(10^{7}-10^{8}\right.$ colony-forming units $\left.(\mathrm{CFU}) / \mathrm{mL}\right)$ were spread on the solid Muller-Hinton medium plates. Filter paper discs, $6 \mathrm{~mm}$ diameter (Whatman No. 1), were individually impregnated with $10 \mu \mathrm{L}$ EO then placed onto the surfaces of the inoculated plates. A positive control containing microbial culture without the $\mathrm{EO}$ and a negative control containing only the medium were performed as well. At the end of the incubation time $\left(24 \mathrm{~h}\right.$ at $37^{\circ} \mathrm{C}$ for bacteria and $25^{\circ} \mathrm{C}$ for yeast), positive antibacterial and antifungal activities were established by the presence of a measurable inhibition zone and recorded in its width $(\mathrm{mm})$ which includes the disc diameter. Each test was performed in three replicates.

\subsubsection{Determination of the Minimum Inhibitory Concentration (MIC)}

For the determination of the MIC, which represents the concentration that completely inhibits the growth of microorganisms, a micro dilution broth susceptibility assay was used as recommended by Chemat et al. [74]. Dilution series were made in a concentration range from $10 \mu \mathrm{L}$ to $40 \mu \mathrm{L} / \mathrm{mL}$ of the EO in sterile test tubes containing nutrient broth (NB) medium. Using a vortex, each tube was vigorously stirred in order to perfectly disperse the EO in the culture medium. Then, $15 \mu \mathrm{L}$ of the tested microorganism suspension $\left(10^{7}-10^{8}\right.$ colony-forming units $\left.(\mathrm{CFU}) / \mathrm{mL}\right)$ were inoculated into a test tube and incubated for $24 \mathrm{~h}$ in an oven at $37^{\circ} \mathrm{C}$ for bacteria and $25^{\circ} \mathrm{C}$ for yeast. A positive control containing microbial suspension without the $\mathrm{EO}$ and a negative control containing only the medium were performed. The MIC value was assimilated to the smallest concentration of the samples that did not become turbid. Each test was performed three times.

\section{Conclusions}

The solvent-free microwave extraction (SFME) technique has been compared with the conventional hydro-distillation (HD) method, for extraction of EO from Egyptian basil (O. basilicum L.) leaves. SFME was found to be highly effective enabling a considerable reduction in extraction time (30 min for SFME against 60 min for HD), providing an EO with yields similar to those of conventional HD. GC-MS results indicated that there were no significant differences between the constituents of EO obtained by SFME and those obtained by conventional HD. The results reported on the chemical composition of basil oil reveal that linalool represents the main compound in basil oil. Both essential oils SFME-EO and HD-EO indicate strong antimicrobial and low antioxidant activities and also a notable TPM effect. However, SFME-EO showed a better antimicrobial activity than HD-EO against all tested microorganisms, a greater antioxidant activity in the DPPH ${ }^{\bullet}$ test and displayed an improved stability to virgin OO. SFME can be considered as a green technology that offers significant advantages over traditional hydro-distillation: shorter extraction times with similar yields, substantial energy and solvent saving, environmentally friendly approach, and lower cost. Thus, this method appears to be a good alternative for the extraction of EO from sweet basil for their applications in the food, pharmaceutical, and cosmetic industries. 
Acknowledgments: We would like to thank the technical staff at the Green Extraction Team, University of Avignon and all laboratory colleagues for their skillful technical assistance. Also, we are grateful acknowledge to F.Z. Fortas (Laboratoire de Biologie des microorganismes et de Biotechnologie de l'Université d'Oran 1 Ahmed Benbella) for testing antimicrobial activity.

Author Contributions: F.C. designed research; C.M., D.E.A., N.R. and X.F. performed the research and analyzed the data; C.M. and D.E.A., wrote the paper. All authors read and approved the final manuscript.

Conflicts of Interest: The authors declare no conflict of interest.

\section{References}

1. Bakkali, F.; Averbeck, S.; Averbeck, D.; Idaomar, M. Biological effect essential oils-A review. Food Chem. Toxicol. 2008, 46, 446-475. [CrossRef] [PubMed]

2. Teles Andrade, B.F.M.; Barbosa, L.N.; da Silva Probst, I.; Fernandes Júnior, A. Antimicrobial activity of essential oils. J. Essent. Oil Res. 2014, 26, 34-40. [CrossRef]

3. Burt, S. Essentials oils: Their antibacterial properties and potential applications in foods-A review. Int. J. Food Microbiol. 2004, 94, 223-253. [CrossRef] [PubMed]

4. Delille, L. Les Plantes Médicinales D'Algérie; BERTI: Algiers, Algeria, 2007; pp. 47-48.

5. Hanif, M.A.; Al-Maskari, M.Y.; Al-Maskari, A.; Al-Shukaili, A.; Al-Maskari, A.Y.; Al-Sabahi, J.N. Essential oil composition antimicrobial and antioxidant activities of unexplored Omani basil. J. Med. Plants Res. 2011, 5, 751-757.

6. Simon, J.E.; Morales, M.R.; Phippen, W.B.; Vieira, R.F.; Hao, Z. Basil: A source of aroma compounds and a popular culinary and ornamental herb. In Perspectives on New Crops and New Uses; Janick, J., Ed.; ASHS Press: Alexandria, VA, USA, 1999; pp. 499-505.

7. Simon, J.E.; Quinn, J.; Murray, R.G. Basil: A source of essential oils. In Advances in New Crops; Janick, J., Simon, J.E., Eds.; Timber Press: Portland, OR, USA, 1990; pp. 484-489.

8. Duke, J.A.; Bogenschutz-Godwin, M.J.; DuCellier, J.; Duke, P.A.K. Handbook of Medicinal Herbs, 2nd ed.; CRC Press: Boca Raton, FL, USA, 2008; pp. 60-62.

9. Khalid, Kh.A.; Hendawy, S.F.; El-Gezawy, E. Ocimum basilicum L. production under organic farming. Res. J. Agric. Biol. Sci. 2006, 2, 25-32.

10. Marotti, M.; Piccaglia, R.; Giovanelli, E. Differences in essential oil composition of basil (Ocimum basilicum L.) Italian cultivars related to morphological characteristics. J. Agric. Food Chem. 1996, 44, 3926-3929. [CrossRef]

11. Grayer, R.J.; Kite, G.C.; Goldstone, F.J.; Bryan, S.E.; Paton, A.; Putiesky, E. Intraspecific taxonomy and essential oil chemotypes in Sweet Basil, Ocimum basilicum. Phytochemistry 1996, 43, 1033-1039. [CrossRef]

12. Chalchat, J.C.; Garry, R.P.; Sidibe, L.; Marama, M. Aromatic plants of Mali (I): Chemical composition of essential oils of Ocimum basilicum L. J. Essent. Oil Res. 1999, 11, 375-380. [CrossRef]

13. Lawrence, B.M. Progress in Essential oils: Basil oil. Perfum. Flavor. 1998, 23, 35-52.

14. Franz, C.; Novak, J. Sources of essential oils. In Handbook of Essential Oils: Science, Technology, and Applications; Baser, K.C.H., Buchbauer, G., Eds.; CRC Press Taylor \& Francis Group: Boca Raton, FL, USA, 2010; pp. $39-81$.

15. Chemat, F. Techniques for oil extraction. In Citrus Essential Oils: Flavor and Fragrance; Sawamura, M., Ed.; Wiley: Hoboken, NJ, USA, 2011; pp. 9-20.

16. Chemat, F.; Smadja, J.; Lucchesie, M.E. Solvent Free Microwave Extraction of Volatile Natural Compound. EP Patent 1,439,218 B1, 28 July 2004.

17. Chemat, F.; Lucchesie, M.E.; Smadja, J. Solvent free microwave extraction: An innovative tool for rapid extraction of essential oil from aromatic herbs and spices. Int. Microw. Power Inst. 2004, 39, 135-139.

18. Lucchesie, M.E.; Chemat, F.; Smadja, J. Solvent free microwave extraction of essential oil from aromatic herbs: Comparison with conventional hydrodistillation. J. Chromatogr. A 2004, 1043, 323-327. [CrossRef]

19. Asghari, J.; Touli, C.K.; Mazaheritehrani, M.; Aghdasi, M. Comparison of the Microwave-assisted hydrodistillation with the traditional hydrodistillation method in the extraction of essential oils from Ferulago angulate (Schelcht.) boiss. Eur. J. Med. Plants 2012, 2, 324-334. [CrossRef]

20. Filly, A.; Fernandez, X.; Minuti, M.; Visinoni, F.; Cravotto, G.; Chemat, F. Solvent free microwave extraction of essential oil from aromatic herbs: From laboratory to pilot and industrial scale. Food Chem. 2014, 150, 193-198. [CrossRef] [PubMed] 
21. Figueredo, G.; Ünver, A.; Chalchat, J.C.; Arsalan, D.; Özcan, M.M. A research on the compostion of essential oil isolated from some aromatic plants by microwave and hydroditillation. J. Food Biochem. 2012, 6, 334-343. [CrossRef]

22. Pandey, A.K.; Singh, P.; Tripathi, N.N. Chemistry and bioactivities of essential oils of some Ocimum species: An Overview. Asian Pac. J. Trop. Biomed. 2014, 4, 682-694. [CrossRef]

23. Oliveira, J.S.; Porto, L.A.; Estevam, C.S.; Siqueira, R.S.; Alves, P.B.; Niculau, E.S.; Blank, A.F.; Reinaldo, N.; Almeida, R.N.; Marchioro, M.; et al. Phytochemical screening and anticonvulsant property of Ocimum basilicum leaf essential oil. Bol. Latinoam. Caribe Plantas Med. Aromát. 2009, 8, 195-202.

24. Nurzyńska-Wierdak, R.; Borowski, B.; Dzida, K.; Zawiślak, G.; Kowalski, R. Essential oil composition of sweet basil cultivars as affected by nitrogen and potassium fertilization. Turk. J. Agric. For. 2013, 37, 427-436. [CrossRef]

25. Klimankova, E.; Holadova, K.; Hajslova, J.; Cajka, T.; Poustka, J.; Koudela, M. Aroma profiles of five basil (Ocimum basilicum L.) cultivars grown under conventional and organic conditions. Food Chem. 2008, 107, 464-472. [CrossRef]

26. Keita, S.M.; Vincent, C.; Schmit, J.P.; Belanger, A. Essential oil composition of Ocimum basilicum L., O. gratissium L. and O. suave L. in the Republic of Guinea. Flavour Fragr. J. 2000, 15, 339-341. [CrossRef]

27. Politeo, O.; Jukic, M.; Milos, M. Chemical composition and antioxidant capacity of free volatile aglycones from basil (Ocimum basilicum L.) compared with its essential oil. Food Chem. 2007, 101, 379-385. [CrossRef]

28. Opalchenova, G.; Obreshkova, D. Comparative studies on the activity of basil-An essential oil from Ocimum basilicum L. against multidrug resistant clinical isolates of the genera Staphylococcus, Enterococcus and Pseudomonas by using different test methods. J. Microbiol. Methods 2003, 54, 105-110. [CrossRef]

29. Lee, S.J.; Umano, K.; Shibamoto, T.; Lee, K.G. Identification of volatile components in basil (Ocimum basilicum L.) and thyme leaves (Thymus vulgaris L.) and their antioxidant properties. Food Chem. 2005, 91, 131-137. [CrossRef]

30. Benedec, D.; Oniga, I.; Oprean, R.; Tamas, M. Chemical composition of the essential oils of Ocimum basilicum L. cultivated in Romania. Farmacia 2009, 57, 625-629.

31. Hadj-Khelifa, L.; Brada, M.; Brahmi, F.; Achour, D.; Fauconnier, M.L.; Lognay, G. Chemical composition and antioxidant activity of essential oil of Ocimum basilicum leaves from the northern region of Algeria. Topcl. J. Herb. Med. 2012, 1, 25-30.

32. Adam, F.; Vahirua-Lechat, I.; Deslandes, E.; Bessiere, J.M.; Menut, C. Aromatic plants of French Polynesia. III. Constituents of the essential oil of leaves of Ocimum basilicum L. J. Essent. Oil Res. 2009, 21, 237-240. [CrossRef]

33. Hussain, A.I.; Anwar, F.; Sherazi, S.T.H.; Przybylski, R. Chemical composition, antioxidant and antimicrobial activities of basil (Ocimum basilicum) essential oils depends on seasonal variations. Food Chem. 2008, 108, 986-995. [CrossRef] [PubMed]

34. Ismail, M. Central properties and chemical composition of Ocimum basilicum essential oil. Pharm. Biol. 2006, 44, 619-626. [CrossRef]

35. Chalchat, J.C.; Özcan, M.M. Comparative essential oil composition of flowers, leaves and stems of basil (Ocimum basilicum L.) used as herb. Food Chem. 2008, 110, 501-503. [CrossRef] [PubMed]

36. Ramdriamiharisoa, R.; Gaydou, E.M.; Bianchini, J.P.; Ravelojaona, G.; Vernin, G. Study of the variation in the chemical composition and classification of Basil essential oils from Madagascar. Sci. Aliments 1986, 6, 221-231.

37. Shirazi, M.T.; Gholami, H.; Kavoosi, G.; Rowshan, V.; Tafsiry, A. Chemical composition, antioxidant, antimicrobial and cytotoxic activities of Tagetes minuta and Ocimum basilicum essential oils. Food Sci. Nutr. 2014, 2, 146-155. [CrossRef] [PubMed]

38. Bunrathep, S.; Palanuvej, C.; Ruangrungsi, N. Chemical compositions and antioxidative activities of essential oils from four Ocimum Species endemic to Thailand. J. Health Res. 2007, 21, 201-206.

39. Purkayastha, J.; Nath, S.C. Composition of the camphor-rich essential oil of Ocimum basilicum L. native to Northeast India. J. Essent. Oil Res. 2006, 18, 332-344. [CrossRef]

40. Brand-Williams, W.; Cuvelier, M.E.; Berset, C. Use of a free radical method to evaluate antioxidant activity. Food Sci. Technol. 1998, 28, 25-30. [CrossRef]

41. Shafique, M.; Khan, S.J.; Khan, N.H. Study of antioxidant and antimicrobial activity of sweet basil (Ocimum basilicum) essential oil. Pharmacologyonline 2011, 1, 105-111. 
42. Taie, H.A.A.; Salama, Z.A.R.; Radwan, S. Potential activity of Basil plants as a source of antioxidants and anticancer agents as affected by organic and bio-organic fertilization. Not. Bot. Hortic Agrobot. Cluj 2010, 38, 119-127.

43. Bassole, I.H.N.; Lamien-Meda, A.; Bayala, B.; Tirogo, S.; Franz, C.; Novak, J.; Nebié, R.C.; Dicko, M.H. Composition and antimicrobial activities of Lippia multiflora Moldenke, Mentha x piperita L. and Ocimum basilicum L. essential oils and their major monoterpene alcohols alone and in combination. Molecules 2010, 15, 7825-7839. [CrossRef] [PubMed]

44. Vlase, L.; Benedec, D.; Daniela Hanganu, D.; Damian, G.; Sevastre, B.; Mot, A.C.; Silaghi-Dumitrescu, R.; Ioan Csillag, I.; Tilea, I. Evaluation of antioxidant and antimicrobial activities and phenolic profile for Hyssopus officinalis, Ocimum basilicum and Teucrium chamaedrys. Molecules 2014, 19, 5490-5507. [CrossRef] [PubMed]

45. Bayala, B.; Bassole, I.H.N.; Gnoula, C.; Nebie, R.; Yonli, A. Chemical composition, antioxidant, anti-inflammatory and anti-proliferative activities of essential oils of plants from Burkina Faso. PLoS ONE 2014, 9, e92122. [CrossRef] [PubMed]

46. Bozin, B.; Mimica-Dukic, N.; Simin, N.; Anackovj, G. Characterization of the volatile composition of essential oils of some lamiaceae spices and the antimicrobial and antioxidant activities of the entire oils. J. Agric. Food Chem. 2006, 54, 1822-1828. [CrossRef] [PubMed]

47. Mahmoud, G.I. Biological effects, antioxidant and anticancer activities of marigold and basil essential oils. J. Med. Plants Res. 2013, 7, 561-572.

48. Dawidowicz, A.L.; Olszowy, M. Does antioxidant properties of the main component of essential oil reflect its antioxidant properties? The comparison of antioxidant properties of essential oils and their main components. Nat. Prod. Res. 2014, 28, 1952-1963. [CrossRef] [PubMed]

49. Mimica-Dukic, N.; Bugarin, D.; Grbovic, S.; Mitic-Culafic, D.; Vukovic-Gacic, B.; Orcic, D.; Jovin, E.; Couladis, M. Essential oil of Myrtus communis L. as a potential antioxidant and antimutagenic agents. Molecules 2010, 15, 2759-2770. [CrossRef] [PubMed]

50. Nagababu, E.; Lakshmaiah, N. Inhibitory effect of eugenol on non-enzymatic lipid peroxidation in rat liver mitochondria. Biochem. Pharmacol. 1992, 43, 2393-2400. [CrossRef]

51. Jaganathan, S.K.; Supriyanto, E. Antiproliferative and molecular mechanism of eugenol-induced apoptosis in cancer cells. Molecules 2012, 17, 6290-6304. [CrossRef] [PubMed]

52. Ali, S.; Prasad, R.; Mahmood, A.; Routray, I.; Shinkafi, T.S.; Sahin, K.; Kucuk, O. Eugenol-rich fraction of Syzygium aromaticum (clove) reverses biochemical and histopathological changes in liver cirrhosis and inhibits hepatic cell proliferation. J. Cancer Prev. 2014, 19, 288-300. [CrossRef] [PubMed]

53. Pripdeevech, P.; Chumpolsri, W.; Suttiarporn, P.; Wongpornchai, S. The chemical composition and antioxidant activities of basil from Thailand using retention indices and comprehensive two-dimensional gas chromatography. J. Serbian Chem. Soc. 2010, 75, 1503-1513. [CrossRef]

54. Dabire, C.; Roger, H.C.; Nebie, R.H.C.; Belanger, A.; Nacro, M.; Sib, F.S. Effet du séchage de la matière végétale sur la composition chimique de l'huile essentielle et l'activité antioxydante d'extraits d'Ocimum basilicum L. Int. J. Biol. Chem. Sci. 2011, 5, 1082-1095.

55. Achat, S.; Tomao, V.; Madani, K.; Chibane, M.; Elmaataoui, M.; Dangles, O.; Chemat, F. Direct enrichment of olive oil in oleuropein by ultrasound-assisted maceration at laboratory and pilot plant scale. Ultrason. Sonochem. 2012, 19, 777-786. [CrossRef] [PubMed]

56. Casal, S.; Malheiro, R.; Sendas, A.; Oliveira, B.P.P.; Pereira, J.A. Olive oil stability under deep-frying conditions. Food Chem. Toxicol. 2010, 48, 2972-2979. [CrossRef] [PubMed]

57. Mnayer, D.; Fabiano-Tixier, A.S.; Petitcolas, E.; Hamieh, T.; Nehme, N.; Ferrant, C.; Fernandez, X.; Chemat, F. Chemical composition, antibacterial and antioxidant activities of six essentials oils from the Alliaceae family. Molecules 2014, 19, 20034-20053. [CrossRef] [PubMed]

58. Suppakul, P.; Miltz, J.; Sonneveld, K.; Bigger, S.W. Antimicrobial properties of Basil and its possible application in food packaging. J. Agric. Food Chem. 2003, 51, 3197-3207. [CrossRef] [PubMed]

59. Zhang, J.W.; Li, S.K.; Wu, W.J. The Main chemical composition and in vitro antifungal activity of the essential oils of Ocimum basilicum Linn. Var. pilosum (Willd.) Benth. Molecules 2009, 14, 273-278. [PubMed]

60. Ouibrahim, A.; Tlili-Ait-kaki, Y.; Bennadja, S.; Amrouni, S.; Djahoudi, A.G.; Djebar, M.R. Evaluation of antibacterial activity of Laurus nobilis L., Rosmarinus officinalis L. and Ocimum basilicum L. from Northeast of Algeria. Afr. J. Microbiol. Res. 2013, 7, 4968-4973. 
61. Sienkiewicz, M.; Lysakowska, M.; Pastuszka, M.; Bienias, W.; Kowalczyk, E. The potential of use Basil and Rosemary essential oils as effective antibacterial agents. Molecules 2013, 18, 9334-9351. [CrossRef] [PubMed]

62. Moghaddam, M.; Alymanesh, M.R.; Mehdizadeh, L.; Mirzaei, H.; Pirbalouti, A.G. Chemical composition and antibacterial activity of essential oil of Ocimum ciliatum, as a new source of methyl chavicol, against ten phytopathogens. Ind. Crops Prod. 2014, 59, 144-148. [CrossRef]

63. Lopez, P.; Sanchez, C.; Batlle, R.; Nerin, C. Solid- and Vapor-phase antimicrobial activities of six essential oils: Susceptibility of selected foodborne bacterial and fungal strains. J. Agric. Food Chem. 2005, 53, 6939-6946. [CrossRef] [PubMed]

64. Lachowicz, K.J.; Jones, G.P.; Briggs, D.R.; Bienvenu, F.E.; Wan, J.; Wilcock, A.; Coventry, M.J. The synergistic preservative effects of the essential oils of sweet basil (Ocimum basilicum L.) against acid-tolerant food micro flora. Lett. Appl. Microbiol. 1998, 26, 209-214. [CrossRef] [PubMed]

65. Bassole, I.H.N.; Juliani, H.R. Essential oils in combination and their antimicrobial properties. Molecules 2012, 17, 3989-4006. [CrossRef] [PubMed]

66. Joulain, D.; König, W.A. The Atlas of Spectral Data of Sesquiterpene Hydrocarbons; E.B-Verlag: Hamburg, Germany, 1998; p. 658.

67. Joulain, D.; König, W.; Hochmuth, D.H. Terpenoids and Related Constituents of Essential Oils; Library of Mass Finder 2.1; Institute of Organic Chemistry: Hamburg, Germany, 2001.

68. McLafferty, F.W.; Stauffer, D.B. The Wiley/Nbs Registry of Mass Spectral Data; Wiley J \& Sons: New York, NY, USA, 1989; p. 7872.

69. BACIS. ESO 2000 the Complete Database of Essential Oils; Boelens Aroma Chemical Information Service: Huizen, The Netherlands, 1999.

70. AFNOR (Association Française de Normalisation). Huiles Essentielles; AFNOR: Paris, France, 2007.

71. Sanli, H.; Canakci, M.; Alptekin, E. Characterization of waste frying oils obtained from different facilities. In Proceedings of the World Renewable Energy Congress, Linköping, Sweden, 8-13 May 2011; Bioenergy Technology: Linköping, Sweden, 2011; pp. 479-485.

72. Berghe, D.A.V.; Vlietinck, A.J. Screening methods for antibacterial and antiviral agents from higher plants. Plant Biochem. 1991, 6, 47-69.

73. Cappuccino, J.G.; Sherman, N. Microbiology: A Laboratory Manual, 5th ed.; Benjamin/Cumming Science Publishing: San Francisco, CA, USA, 1998; p. 254.

74. Chemat, F.; Fabiano-Tixier, A.S.; Hellal, A.; Boutekedjiret, C.; Fernandez, X. Activités chimiques et biologiques des huiles essentielles. In La Chimie des Huiles Essentielles: Tradition et Innovation; Fernandez, X., Chemat, F., Eds.; Vuibert: Paris, France, 2012; pp. 229-232.

Sample Availability: Not Available.

(C) 2016 by the authors; licensee MDPI, Basel, Switzerland. This article is an open access article distributed under the terms and conditions of the Creative Commons by Attribution (CC-BY) license (http://creativecommons.org/licenses/by/4.0/). 